\title{
ROUTES TO THE DÜBEN COLLECTION THE ACQUISITION OF MUSIC BY GUSTAV DÜBEN AND HIS SONS
}

\author{
LARS BERGLUND \\ Uppsala University
}

\begin{abstract}
Izvleček: Razprava opisuje, na kakšne načine so prihajale muzikalije v Dübnovo zbirko. Glasbo so zanjo prepisovali iz tiskov, so pa tudi iz raznih predelov Evrope pridobivali cele skupine rokopisnih prepisov. Zdi se,da so bila tesna osebna prijateljstva in zasebne mreže pri tem pomembnejše kot uradne tržne poti.
\end{abstract}

Ključne besede: Dübnova zbirka, 17. stoletje, glasba na Švedskem, razširjanje glasbe, zbirke.

\begin{abstract}
The article describes the practices of acquisition of music behind the Düben Collection. Music was copied into manuscripts from prints, but was also obtained in the form of groups of manuscripts from different regions of Europe. Close personal contacts and networks seem to have been more important than traditional trade routes.
\end{abstract}

Keywords: Düben Collection, seventeenth century, music in Sweden, dissemination, music collections.

Musical-cultural interchange and the transfer of music and musical cultures constitute in effect an exchange of knowledge, skills and values. In early modern Europe music travelled across the continent, being adopted, imitated and integrated in local contexts, often in cross-fertilization with local practices. Encounters with new and foreign sounds could be uncritically embraced - or resisted and rejected - but they always led to some kind of transformation of attitudes to listening, playing, composing or otherwise interacting with music.

Even though transnational and transcultural interchange effectively entailed mental transformations of this kind, cultural transfer had in some way or other to be mediated by material means - by the transfer of material objects such as music prints or manuscripts, instruments or educational treatises: a transfer basically carried out by humans, who might be migratory musicians, postal carriers, shippers or couriers. So in order to make a historical reconstruction and interpretation of the mental aspects of cultural interchange one needs to reconstruct and describe the material processes that made this possible.

The Düben Collection at Uppsala University Library (S-Uu) is uncommonly well suited to serve as a case study for such processes. It is remarkably well preserved, being more or less unaffected by antiquarian reconstruction, and it is unusually international 
in scope. Moreover, thanks to recent research, it is today possible to give an almost conclusive account of the routes of transfer and acquisition.

\section{The Düben Collection: A Brief Presentation}

The so-called Düben Collection comprises musical manuscripts and prints that belonged to members of the Düben family, who during a period of more than eighty years were in charge of music at the royal court of Sweden. Four members of the family spanning three generations succeeded one other as Hofkapellmeister. Their tenures as leaders of the royal music were as follows: ${ }^{1}$

$\begin{array}{ll}\text { Andreas Düben } & 1640-1662 \\ \text { Gustav Düben the elder } & 1663-1690 \\ \text { Gustav Düben the younger } & 1690-1698 \\ \text { Anders (von) Düben } & 1698-1726\end{array}$

In 1732 the entire collection was donated by Anders von Düben, the last Hofkapellmeister in the family succession. ${ }^{2}$ This donation formed part of a series of donations to the Uppsala Academy by von Düben, which also comprised books and paintings. ${ }^{3}$ At this juncture Anders von Düben had been ennobled as a baron and appointed Marshal of the Court (hovmarskalk). This was an extraordinary career for a court musician in early modern Europe.

The major part of the collection was assembled by Gustav the elder between 1663 and 1690, some material being added by his two sons - not least, the French sub-collection, to which we will return. The collection mirrors their activities as musicians in Stockholm in a broad sense. Gustav the elder was not merely the Hofkapellmeister but also the organist for the German congregation, for whose services much of the sacred music in the collection seems to have been prepared. Some occasional music in the collection was prepared by Gustav Düben for weddings and funerals. ${ }^{4}$ There is also some material reflecting Gustav's activities before he became Hofkapellmeister in 1663.

The collection consists of around three thousand manuscript sources, which include both sets of partbooks and tablature scores, amounting to two thousand, two hundred and fifty works in manuscript. It also contains over a hundred and fifty music prints, totalling approximately two to three thousand additional compositions. The proportion of music in the collection composed and produced in Sweden is remarkably small. A rough estimate suggests that it runs to some hundred and fifty works, making up less than a tenth of the works preserved in manuscript in the collection. A reason behind this relative scarcity

1 Kjellberg, Kungliga musiker i Sverige under stormaktstiden.

2 The formal donation was made in 1732, whereas the actual transportation of the collection from Stockholm to Uppsala took place in January 1733.

3 Lindberg, "Katalog över Dübensamlingen," 6; see also Schildt, Gustav Düben at Work, 31-36, 79-82.

4 Schildt, Gustav Düben at Work, 373-449. 
is that the members of the Düben family were neither very prolific nor very productive as composers. They were consequently obliged to acquire music by other persons, who were mainly composers active outside Sweden. This situation to some extent accounts for the unique character of the collection.

At this point, one important thing needs to be emphasized. The historical Düben Collection in the possession of the Düben family did not constitute a "collection" in the strict sense of the word. It was never assembled for the specific purpose of collecting. ${ }^{5}$ It is made up of performance material that the members of the Düben family acquired or produced in order to carry out their professional duties. In preparation for its donation to Uppsala University this material was packed into two chests in the simple state in which the material happened to be preserved at that point. One might argue that the musicalia mutated into an actual collection when they were donated to Uppsala University. At that point, artefacts became transformed from "things" into "semaphores," to borrow the terminology of Krzysztof Pomian. Pomian defines "things" as objects that are useful, can be handled, consumed, undergo modification and be gradually worn out. He contrasts these with "semaphores," which he defines as objects that are of no practical utility, are put on display, can neither be consumed nor modified and never wear out. ${ }^{6}$

To clarify this difference, Maria Schildt introduced a distinction between The Düben Collection on the one hand, and The Düben Family Music Library on the other. ${ }^{7}$ The Düben Collection is thus the content of the two chests that was transported over the ice from Stockholm to arrive in Uppsala in January 1733: that is, the actual donation. ${ }^{8}$ The Düben Family Music Library was the variable stock of music in possession of family members at different times, for use in their professional duties. This was in constant flux on account of not only new acquisitions but also, presumably, losses. Material was weeded out or given away; outworn parts were discarded and sometimes replaced; presumably, some material simply disappeared by accident. The Düben Collection is thus a momentary incarnation of the Music Library that happened to become frozen and preserved at the precise point when it was packed and sent to Uppsala. We do not know exactly to what extent Anders von Düben made a selection at that point, but, judging from the make-up of the collection, it would appear that he did not omit anything but simply packed the library just as it stood at the time. There are no hints that he reorganized or sorted the material in the process.

This makes the Düben Collection quite unique. It is an unsorted stock of musical performance material from a northern European court, almost untouched by collectors or librarians. It contains the sheets of music actually placed on music stands by the court musicians - sheets that often bear traces of different performance occasions or of reworkings and rearrangements of the music. This makes the material invaluable for our understanding of everyday musical practices at an early modern European court.

\footnotetext{
5 Pomian, Collectionneurs, amateurs et curieux.

6 Ibid.

7 Schildt, Gustav Düben at Work, 26-27.

8 Lindberg, Introduction to "Katalog över Dübensamlingen," 6-9.
} 


\section{The Düben Collection Database Catalogue Project}

Since 2006 digital scans of the Düben Collection have been available online, being linked from a catalogue with substantial metadata. ${ }^{9}$ This project was initiated by Kerala J. Snyder and Erik Kjellberg already in the 1990s. After some preparatory work the digitization project proper started in 2003, with a grant from the Swedish Foundation for Humanities and Social Sciences. The version published online in 2006 covered close to ninety per cent of the manuscript collection. Subsequently, it has gradually been added to and refined, and this process of refining is due to continue indefinitely. The catalogue is conceived as a dynamic resource that is constantly being updated in step with new research findings. In 2014 a new grant was secured from the Swedish Foundation for Humanities and Social Sciences towards inclusion of the important sub-collection of French stage music.

Apart from the cataloguing and digitization, the following aims have informed this large-scale project:

- To mark the Düben Collection off from the other music held by Uppsala University Library,

- To identify the provenance, and trace the acquisition, of the prints and manuscripts,

- To date the material with regard to both production and acquisition.

At some point, most likely in connection with the cataloguing of musical manuscripts in Uppsala during the 1880 s, the Düben collection was merged with the other music sources in the Library, sorted into alphabetical order and separated into manuscripts and prints. Hence the precise content of the Düben Collection - that of the actual donation - had to be reconstructed. This work of demarcation and reconstruction, as well as dating and identifying provenance, has fallen to several scholars since the time of Lindberg's first catalogue in the 1940s. ${ }^{10}$ Especially important was the work carried out during the 1960s by Bruno Grusnick, ${ }^{11}$ even though some of Grusnick's finds have been revised by later research and by Jan-Olof Rudén. ${ }^{12}$ More recent contributions have been made by Maria Schildt, Peter Wollny and, to some extent, the present author. Wollny has made some important discoveries, especially concerning material of German provenance. Schildt has produced ground-breaking work on the demarcation of the collection with regard to both manuscripts and prints, and in the refinement of knowledge about the provenance of different source groups..$^{13}$ Thanks to these collective efforts, it is today possible to present a relatively complete picture of the composition of the collection and, not least, to trace the provenance of different groups of manuscripts and the routes of acquisition for the entire collection.

9 The Düben Collection Database Catalogue, edited by Lars Berglund, Kia Hedell, Erik Kjellberg and Kerala J. Snyder: http://www2.musik.uu.se/duben/Duben.php.

${ }^{10}$ Lindberg, "Katalog över Dübensamlingen."

${ }^{11}$ Grusnick, "Die Dübensammlung: ein Versuch ihrer chronologischen Ordnung."

12 Rudén, "Vattenmärken och musikforskning."

${ }^{13}$ Schildt, Gustav Düben at Work. 
The methods applied in this research have been those of traditional musical source criticism:

- $\quad$ Paper identification by watermarks and physical qualities, and comparison with relevant reference material;

- The identification of hands and copyists, with regard to both individuals and workshop styles or regional characteristics;

- The noting of special features in the sources, such as monograms, locations, traces of historical inventories, catalogues etc.;

- Collation with archival documents in order to establish performance occasions or for the purpose of comparing and identifying hands etc.

In the following sections I will try to summarize the most important finds of the last five to ten years of research. The present survey will of necessity be superficial, presenting a broad outline and synthesis. The main focus will be on reconstructing and analysing the networks and practices behind the acquisition of music by members of the Düben family, and especially by Gustav the elder.

\section{The General Composition of the Düben Collection}

The manuscripts in the Düben Collection consist, on one hand, of foreign manuscripts produced outside Sweden and acquired and transferred to Stockholm at some point, and, on the other, of copies produced in Stockholm for local performances. In many cases, these categories interact: the foreign manuscripts were used for performance but were often supplemented by new parts or scores copied in Stockholm. Hence there are often at least two different representations of the same music: one set of parts and one tablature score. The tablatures were most likely used for performance. ${ }^{14} \mathrm{~A}$ rare feature is the fact that so many of the foreign originals used for the copying of performance parts or scores are actually still present in the collection. As we shall see, this opens up unique possibilities for tracing the routes of acquisition of the music.

A substantial portion of the locally produced manuscripts have been copied from printed collections. Just as in the case of the foreign manuscripts, the prints serving as copy texts are in several cases preserved within the collection or else in the collection of the German Church. ${ }^{15}$ A list of all concordances identified between manuscripts in the Düben Collection and printed volumes, prepared by Maria Schildt, is published on the Düben Catalogue website. ${ }^{16}$

One result of this particular make-up of the sources is that the Düben Collection is a unique fount of knowledge not only regarding local musical practices at the Swedish court but also regarding those regions and institutions from where the foreign manuscripts

${ }^{14}$ Ibid., 76-78.

15 Today at Musik- och teaterbiblioteket in Stockholm.

${ }^{16}$ See http://www2.musik.uu.se/duben/Concordances.pdf. 
originated, since at several of those localities much of the musical source material has been lost. This is the case with the city of Danzig (present-day Gdańsk), several towns and courts within Saxony and also the cities of Lübeck and Hamburg. But it is to some extent also relevant for important cultural centres such as Paris and Rome.

With regard to the manuscripts acquired from outside Sweden, the so-called foreign manuscripts, it has been possible to identify some particularly important groups.

\section{The Roman Manuscripts and Prints}

To begin with, there is a group of Italian manuscripts and prints brought to Sweden by an Italian ensemble employed at Queen Christina's court between 1652 and 1654. This ensemble was recruited mainly in Rome, with Vincenzo Albrici as its maestro di cappella. It numbered over twenty members, including no fewer than six castrato singers. ${ }^{17}$

This complex contains about fifteen compositions in manuscript originating from Rome, including a unique source of a musical Vesper setting by Francesco Foggia (16041688), maestro di cappella at the Lateran basilica. ${ }^{18}$ In addition to the manuscripts copied on Italian paper, there are also around fifty works preserved in manuscripts copied in Sweden by the Italian musicians and by Gustav Düben and his colleagues from originals brought by the former. Among this material we find several motets by Giacomo Carissimi transmitted exclusively in manuscripts, some of which are unica. ${ }^{19}$ There are also several compositions by Vincenzo Albrici produced during his stay in Sweden, including a few parts in autograph manuscript, plus one composition by Alessandro Cecconi, impresario for the ensemble, who was later appointed Queen Christina's valet de chambre. In addition to these manuscripts, there are a few music prints from Rome that most likely were similarly brought to Sweden by the same Italian musicians, including Francesco Foggia's Concentus ecclesiastici of $1645,{ }^{20}$ and three of Florido de Silvestri's anthologies. ${ }^{21}$ In addition to the material in the Düben Collection, there are also manuscripts in the Royal Library of Stockholm and Christ Church Library in Oxford originating from the visit of this Italian ensemble. ${ }^{22}$

The likely reason why this material became part of the Düben Collection was that the still relatively young Gustav Düben was deputed by his father to work with the Italian musicians, together with some other young members of the court musical establishment, possibly as part of their continuing musical education. ${ }^{23}$ The early layers of the Collection,

${ }^{17}$ We will present new finds regarding the recruitment process, the repertoire and the source material in a forthcoming study: Berglund and Schildt, "Italian Music at the Swedish Royal Court of Queen Christina."

${ }^{18} \mathrm{~S}-\mathrm{Uu}, \mathrm{Vmhs}$ 23:1-11.

${ }^{19}$ Simile est regnum caelorum, CC, bc (in F), and Surrexit pastor bonus, CCC, bc (also in F), both copied into the partbooks of S-Uu, Vmhs 53:10.

${ }^{20}$ Francesco Foggia, Concentus ecclesiastici (Roma: Giovanni Domenico Franzini, 1645).

${ }^{21} \mathrm{~S}-U u$, Uvmtr 553-557, 544-548 and 549-552 (RISM 1647², 16494 and 16523).

${ }^{22}$ Webber, "Italian Music at the Court of Queen Christina."

${ }^{23}$ The others were Fredrick Scharle, Hans Heinrich Tauscher and possibly also Gustav's brother 
dating from the period before 1663 when Gustav Düben was appointed Hofkapellmeister, comprise music collected by Gustav Düben himself, rather than being remnants of the music library of his father, Andreas Düben. ${ }^{24}$

The manuscripts and prints that arrived with the Italian ensemble represent the material in the Düben Collection that travelled the furthest distance across Europe. They were the result of extraordinary circumstances: Queen Christina's ambitions for her Stockholm court in terms of art and letters, but also, and more importantly, her already well-advanced plans to abdicate, convert to Catholicism and move to Rome. The material seems to have been retained by the Düben Collection by virtue of the fact that Gustav Düben was assigned to work with the Italian ensemble and was able to keep some of the material that passed through his hands. These chance circumstances aside, the brief visit of the Italian musicians had a lasting impact on the music at court, as well as on Gustav Düben's own practices and preferences. ${ }^{25}$

Another early manuscript with a similar background is the single tablature volume Imhs 409, which contains a large number of dance movements in the French style copied by Gustav Düben from the early 1650s onwards. This volume resulted from Düben's contact with a French violin band recruited for Stockholm in 1647. It contains some of the earliest preserved ballroom dances from the French court, by composers such as Jacques de Belleville, Michel Mazuel and Louis Constantin, ${ }^{26}$ plus essays in the composition of dances in the French style by Gustav Düben himself, his brother Peter and his father Andreas. ${ }^{27}$

\section{Manuscripts from Danzig}

One group of manuscripts in the Düben Collection originates from the city of Danzig and contains around fifty compositions. It was presumably acquired by Gustav Düben in the early $1660 \mathrm{~s}$, but the manuscripts appear to be older than that: from the $1650 \mathrm{~s}$ or even earlier. This could possibly be a small collection previously owned by a musician in Danzig that Düben acquired through an unknown intermediary. The connection to Danzig is confirmed by the use of papers from the Danzig paper mill of Nathanael Propstly, with its characteristic watermark in the shape of a fish, and by paper displaying that city's coat of arms. There is also a large representation of composers active in Danzig, who include Crato Bütner, Balthasar Erben, Kaspar Förster junior and Thomas Strutius. ${ }^{28}$

Peter Düben; see Berglund and Schildt, "Italian Music at the Swedish Royal Court of Queen Christina."

${ }^{24}$ A qualified guess is that that older collection was destroyed in the fire at the royal castle in 1697.

${ }^{25}$ Berglund, "Roman Connection."

${ }^{26}$ Some of the dances have concordances in the Philidor manuscript "Recueil de plusieurs vieux Airs," Paris, Bibliothèque nationale de France, Département de la Musique, Rés. F 494; Robertson, Courtly Consort Suite in German-Speaking Europe, 41-45. The entire volume was edited by Jaroslav J. S. Mrácek in Seventeenth-century Instrumental Dance Music.

${ }^{27}$ These attributions have been disputed, but were convincingly confirmed in Schildt, Gustav Düben at Work, 101-107; cf. Wollny, "Zur Thüringer Rezeption des französischen Stils."

${ }^{28}$ The origin of the material will possibly be clarified when the main copyist of the manuscripts, 
Although the principal intermediary is not yet identified, the proximity of Danzig and Stockholm and the well-established trade routes between the two cities could explain the acquisition of these manuscripts. They could conceivably have been obtained by Gustav Düben in connection with a journey to Danzig, but it seems more likely that they arrived with an itinerant musician who sold or otherwise traded them to Düben. ${ }^{29}$

\section{Manuscripts from Saxony}

A group of around sixty manuscripts can be linked to electoral Saxony. ${ }^{30}$ Peter Wollny has argued convincingly that these manuscripts should be associated not primarily with the Saxon Residenzstadt of Dresden, but instead with one of the secondogeniture courts, such as those in Zeitz, Halle and Merseburg. ${ }^{31}$

An absolute majority of the composers represented in this group were active in Saxony, mainly in Dresden. Heinrich Schütz is represented by his Weinachtshistoria, the so-called "Christmas oratorio," including the instrumental parts for the intermediae, which are unica. Further, there is music by, among others, David Pohle, J. Ph. Krieger and Clemens Thieme, as well as by the most prominent Italian composers active in Dresden at this time: Vincenzo Albrici, Gioseppe Peranda and Andrea Bontempi. Wollny's hypothesis that the manuscripts derive from a smaller, secondogeniture court is based on the fact that some minor composers from those centres, such as Heinrich Groh and Christoph Kreichel, are likewise represented.

As in the case of the Danzig manuscripts, the intermediary for these manuscripts is not yet identified, but it may have been a musician or any other person travelling across Europe.

\section{Manuscripts belonging to Johann von Assig und Siegersdorff, from Breslau, Leipzig and Vienna}

In his 1968 manuscript catalogue of the instrumental music of the Düben Collection, Erik Kjellberg called attention to the occurrence of the inscription "assieg" or "assig" in a number of instrumental manuscripts. Peter Wollny was later able to identify their origin. ${ }^{32}$ The approximately forty manuscripts belonged to a nobleman from Breslau, Johann von Assig und Siegerdorff(1650-1694). This man was born in Breslau but studied in Leipzig for a few years around 1670. In Leipzig he acquired music by composers active

the mysterious "Befastru," is identified. The copyist was thus named by Grusnick, using the initials of the composers mentioned above; Grusnick, "Die Dübensammlung," pt. 1, 64.

${ }^{29}$ Manuscripts could have been bought by Düben, but also traded against different services and employments or simply bartered in exchange for other manuscripts.

${ }^{30}$ Bruno Grusnick referred to the individual copyists of these manuscripts simply as "Mitteldeutscher Schreiber". Grusnick, "Die Dübensammlung," pt. 1, 68-69.

${ }^{31}$ Wollny, "Source Complex from Saxony."

${ }^{32}$ Wollny, "Beiträge zur Entstehungsgeschichte der Sammlung Düben." 
there, such as Sebastian Knüpfer and Adam Krieger. In Breslau he had already acquired a small collection of works by musicians in Vienna, who included Antonio Bertali and Johann Helmich Schmelzer.

Following his studies in Leipzig, Johann von Assig und Siegersdorff embarked on a journey through northern Europe, and in the first years of the 1670s he made an appearance in Sweden as a valet de chambre (Kammerjunker or Hofjunker) of the Lord High Chancellor of Sweden, Count Magnus Gabriel de la Gardie, and his consort Maria Euphrosyne. ${ }^{33}$ After a journey to Swedish Livonia he returned in Stockholm in 1676. As a lieutenant commander of the Swedish navy he participated in three naval battles during the Scanian War against Denmark, including the disastrous Battle of Öland on 1 June 1676, where he was badly wounded. In 1676 his father died, and he returned to his native city of Breslau. ${ }^{34}$

The biography of Johann von Assig und Siegersdorff as well as certain dates present in the manuscripts suggest that Gustav Düben acquired the music around 1674 in connection with Assig's sojourn in Stockholm. ${ }^{35}$ It is not possible to determine how Düben obtained possession of them. He could have purchased them or else received them as a gift.

\section{Manuscripts from Gottorp: Augustin Pfleger}

This is a very specific group of around seventy manuscripts in the Düben Collection, comprising an Evangelienjahrgang by Augustin Pfleger, Kapellmeister at Gottorf, Schleswig-Holstein, from 1665 to 1673 . Several of the manuscripts are in Pfleger's own hand, which has been identified by Peter Wollny. ${ }^{36}$ Gustav Düben presumably acquired them during the 1670s ${ }^{37}$ There were close links between the courts of Sweden and Gottorf, since the Swedish Dowager Queen Hedvig Eleonora was a daughter of Frederick III, Duke of Holstein-Gottorp. The music could have reached Stockholm through emissaries, or else Gustav Düben could have acquired them during his travels to that region. During the 1660s and up to 1671 Düben travelled frequently to Lübeck, Hamburg and Amsterdam, these journeys being documented in ship's manifests from Stockholm harbour. ${ }^{38}$

\section{Dietrich Buxtehude Manuscripts from Lübeck}

A remarkable group of manuscripts in the Düben Collection comprises over one hundred vocal works by the organist of the Marienkirche in Lübeck, Dietrich Buxtehude. About a

\footnotetext{
33 Ibid., 106.

${ }^{34}$ Johann von Assig, Herrn Hannß von Aßig, [...], Gesammlete Schrifften, "Vorrede."

${ }^{35}$ For a more detailed argumentation, see Wollny, "Beiträge zur Entstehungsgeschichte der Sammlung Düben," 103-106.

36 Wollny, "Beiträge zur Entstehungsgeschichte der Sammlung Düben," 102.

37 Schildt, Gustav Düben at Work, 279-280.

38 Peetz Ullman, "Eine neue Quelle zu Gustav Dübens Reisen."
} 
tenth of them are preserved in autograph manuscripts, ${ }^{39}$ including the famous dedication to Gustav Düben in the autograph tablature score of Membra Jesu nostri. ${ }^{40}$ This direct contact between Düben and Buxtehude, referred to as a friendship by Buxtehude himself, ${ }^{41}$ explains how this music found its way to Stockholm, even though most of the manuscripts were copied from originals that no longer survive there. These originals could have been sent to Stockholm and returned to Lübeck, or perhaps the manuscripts were copied in Lübeck by Düben's or Buxtehude's assistants.

\section{The North-West German Manuscripts}

Another extraordinary group of manuscripts from the same region was acquired by Gustav Düben in connection with his travels to Lübeck and Hamburg during the 1660s. The main part consists of two large tablature books, Vmhs 79 and 81. The tablatures bound into these two volumes contain music by composers from the region, such as Franz Tunder (Buxtehude's predecessor in Lübeck), Christoph Bernhard and Mattias Weckmann (both active in Hamburg), plus music by composers from more distant parts of Germany, as well as some Italian music. The tablatures were copied by a number of German scribes on paper manufactured in the Lübeck region, including that from the Ratzeburg paper mill. In addition to the tablatures, there are also a number of partbooks with the same provenance. This group contains altogether around one hundred and fifty compositions.

The more precise origin of these manuscripts is yet to be clarified, but several features point to the city of Hamburg. This is one of the most interesting and important complexes within the Düben Collection for several reasons: first, it is the largest group of foreign manuscripts; second, it includes a sizeable number of unica; third, as we shall see, there are strong reasons for believing that a large proportion of the manuscripts produced in Sweden by Gustav Düben and his assistants for which no foreign or printed originals have yet been identified were copied from manuscripts of the same provenance. So this specific supply of music may have been much more important for Gustav Düben than is immediately apparent from the material in question (more on this below).

\section{The Sub-Collection of Stage Music from the French Court}

This sub-collection belongs among the latest material in the Düben Collection, dating from ca. 1690 to the 1720s. It derives mainly from Anders von Düben's tenure as Kapellmeister. It is a collection of operatic music by Jean-Baptiste Lully and his followers, who include, among others, André Campra, Pascal Colasse, André Cardinal Destouches and Henri Desmarets, and runs to around fifty works. The material contains a number of Ballard prints, performance material in manuscript from Paris and performance material in manuscript

\footnotetext{
${ }^{39}$ Wollny, "From Lübeck to Sweden."

40 S-Uu, Vmhs 50:12.

41 "Nobilissimo Amico," Buxtehude writes in the dedication.
} 
prepared in Stockholm. Interestingly, the manuscripts of French origin can be linked to the scriptorium of the music librarian of Louis XIV, André Danican Philidor alias Philidor l'Aîné (1652-1730). ${ }^{42}$ Maria Schildt and the present author have been able to establish that all this material belongs to the Düben Collection..$^{43}$ These manuscripts arrived in Stockholm soon after the original performances at the Académie royale de musique - often within a year. The manuscript parts comprise mainly parties de remplissage, the complementary middle parts omitted in the prints, and some of these are unica, or at least sources earlier in date than their counterparts preserved in France. The Swedish manuscripts represent additional performance parts, but also evidence many instances of adaptation for local court entertainments such as masquerades and ballets.

The prompt arrival of this material in Stockholm was made possible by close contacts with the French court. Anders von Düben studied in Paris for relatively long periods during the 1680s, as did his older brother, Gustav Düben the younger. Moreover, the court entertainments just mentioned were staged by the Swedish court architect Nichodemus Tessin the younger, who was exceptionally well connected in Paris and Versailles and made several sojourns there in the late 1670s and 1680s. Finally, the Swedish resident in Paris, Daniel Cronström, was similarly well connected, and in close contact with a colleague of Philidor, the royal music librarian François Fossard.

\section{Miscellaneous Manuscripts of Foreign Origin}

In addition to the nine groups of manuscripts described above, there are some smaller sets of manuscripts of a more accidental character. One such set is formed by manuscripts that Gustav Düben brought home from his educational journey around Europe in the second half of the 1640s. ${ }^{44}$ There are also thirteen compositions by Johann Valentin Meder, several of which are in Meder's own hand, and which must have been sent or brought to Stockholm by the composer, who was active variously in Reval (now Tallinn), Riga, Danzig and Königsberg (now Kaliningrad). A few manuscripts were also brought from Copenhagen and Mecklenburg by Christian Geist when he arrived in Stockholm in 1670.

\section{Printed Music in the Düben Collection}

In his thesis of 1979 Erik Kjellberg identified around fifty printed collections that could be considered part of the Düben Collection. ${ }^{45}$ In 2014 Maria Schildt was able to add about a hundred more, so that today a hundred and fifty prints can safely be assigned to the Collection. ${ }^{46}$

${ }^{42}$ Berglund and Schildt, "French Stage Music in the Düben Collection, Uppsala."

${ }^{43}$ Ibid.

${ }^{44}$ For more details, see Schildt, Gustav Düben at Work, 87-94.

${ }^{45}$ Kjellberg, Kungliga musiker i Sverige under stormaktstiden.

${ }^{46} \mathrm{~A}$ list of the prints in the collection prepared by Schildt is available from the Düben Collection Database Catalogue webpage: http://www2.musik.uu.se/duben/Printed_Music.pdf. 
Leaving aside the prints from Rome referred to above, the printed items in the Düben Collection mainly come from the German-speaking lands, the Netherlands and Paris. It is not clear how and where they were acquired. Some of them may have been bought in Lübeck, Hamburg or Amsterdam during Düben's travels, or else ordered from booksellers active in those regions.

\section{Manuscripts Copied in Stockholm}

The largest single group of manuscripts in the Düben Collection comprises manuscripts prepared in Stockholm for local performances. Most of them were copied by Gustav Düben himself, while others were the work of court musicians, some of whom have been identified. Another important copyist was Johann Stockman, Kantor at the German Church. ${ }^{47}$

As already mentioned, a large part of those works were copied from prints. The list of such concordances between manuscripts and printed collection prepared by Maria Schildt shows that prints were the single most important source for manuscripts copied in Sweden by Gustav Düben and his assistants.

A smaller, but still substantial, portion of these manuscripts was copied from manuscripts of foreign provenance that still survive in the Düben Collection. The locally produced copies are often complementary in nature: either a tablature score has been intabulated from an imported set of parts, or parts have been prepared from an imported tablature score. The first case is the more common.

In addition to these two larger groups, there are also a number of manuscripts produced locally in Sweden by composers active there. The largest set is formed by the sixty compositions by Christian Geist (ca. 1650-1711) composed during his time as a court musician in Stockholm (1670-1679) and as organist for the German congregation in Göteborg (1679-1684). ${ }^{48}$ Moreover, there are around forty works by members of the Düben family, mainly Gustav the elder and Anders von Düben.

\section{Manuscripts Copied in Sweden and Lacking Known Foreign or Printed Models}

In addition to these different complexes, there is also a relatively large group of manuscripts copied in Sweden that cannot have been taken from printed collections since the music was never printed, and which have no foreign manuscript originals preserved in the Düben Collection. This group is estimated to total over two hundred and fifty compositions.

For these manuscripts, there must have been an original available at some point in time. This original must either have existed previously in Stockholm or elsewhere in Sweden or been accessible to Gustav Düben or his assistants in the context of travels abroad. This raises the question: from which sources were these manuscripts copied? This

47 This copyist was for a long time called "A-Sthlm," an alias used by Bruno Grusnick. Peter Wollny was able to identify the scribe as Johann Stockmann; see Schildt, Gustav Düben at Work, 231.

${ }^{48}$ Berglund, Studier i Christian Geists vokalmusik. 
is one of the last remaining questions relating to how this large collection was gathered. When this enigma has been solved, it will be possible to account for the provenance of almost the entire collection. Some preliminary assumptions may be made regarding this mysterious group of manuscripts.

Either these sources were sent to Stockholm by post or courier, copied in Stockholm and then sent back; or Gustav Düben or someone else travelled to the location of the originals and copied them there. Both possibilities seem to point to relatively accessible locations. Moreover, it is clear from papers, hands and explicit dates that this material was produced not on a single occasion or within a narrow time-frame but with some regularity over a period of more than twenty years. All this implies that we are concerned with a supplier whom Gustav Düben knew quite well: a person with whom he was in constant contact. At the same time, the repertoire in these manuscripts is fairly homogeneous, possibly suggesting a common origin. This is music disseminated only in manuscript and associated with centres in North Germany, and to some extent also Saxony: music by Kaspar Förster, Johann Philip Krieger, Vincenzo Albrici, Giuseppe Peranda, Christoph Bernhard and Franz Tunder.

The attentive reader will have noticed that this repertoire is remarkably similar to the one represented by the North-West German complex of manuscripts discussed above. This suggests that the origin of these Swedish sources without originals in the collection, or at least a large part of them, could be the same as that of the enigmatic North-West German manuscripts. Should this assumption prove correct, we would be able to identify the most important source for Gustav Düben's acquisitions, prints aside. It would account for over four hundred, perhaps even close to five hundred, compositions in manuscript. Although this is still a very tentative assumption, there is much that points to the city of Hamburg. However, this material awaits further study.

\section{Routes of Transfer and Networks of Acquisition - the Düben Collection Unveiled}

The question of how Gustav Düben and his sons managed to assemble their large music collection, with its vast geographical range and its to a large extent unique and exclusive selection of high-quality music, was for a long time considered an enigma among scholars working on the material. Today, as we have seen, it is actually possible to answer these questions, at least regarding the major parts of the collection. To conclude, I would like to present some general observations on this case study in musical transfer.

A first observation is that the transmission of music depended mainly on personal contacts, either direct or indirect, within relatively small and closed networks. Institutionalized networks such as established trade routes were not of importance; nor were cultural, economic or dynastic networks of contact at a more official level. The exception is possibly published music, at least portions of which we may assume were purchased from book dealers or agents in, for instance, Amsterdam or Hamburg.

We can also notice that much of the manuscript music seems to have been received or obtained in the form of "packages" constituting small sub-collections on a single, specific occasion, rather than via a steady stream of individual items. The exceptions are what 
have here been termed the North-West German manuscripts, as well as the Buxtehude manuscripts: cases where the direct contact with a supplier seems to have depended on a long-term relationship, possibly even including an advisory function.

It is also noteworthy that even though some of the sub-collections of manuscripts, such as the North-West German complex and the French material, seem to have been obtained more actively and systematically, with a purpose and a specific use in mind, other acquisitions appear to have been mere coincidences. The best example is the private collection of Johann von Assig und Siegersdorff, but possibly the Danzig manuscripts, too, belong to this category. At the same time, these are also instances suggesting that Gustav Düben eagerly grasped the opportunity to get hold of music whenever such an windfall came his way.

More generally, it is quite clear that the practices of acquiring music reflected in the Düben Collection were marked by careful selection and discrimination. This is particularly true of the selection of works from the published repertoire, a practice that Maria Schildt has investigated. ${ }^{49}$ When Gustav Düben used a printed volume as his copy text for handwritten parts intended for use in performance, he usually selected only two or three pieces out of the twenty or thirty, ${ }^{50}$ always with a keen eye for scorings, texts and musical style. This high level of discrimination is also revealed by the remarkably high quality of the musical repertoire disseminated only in manuscript.

The compositions preserved in manuscripts copied in Sweden are very often adapted and rearranged for local uses and needs. They are re-scored, re-texted and during the 1690s also often abridged. Moreover, in many cases the manuscripts betray layers of different performance occasions, running from the early $1660 \mathrm{~s}$ up to the late $1690 \mathrm{~s} .{ }^{51}$

I would like to close with some methodological remarks. The most important research observations regarding routes and practices of assembling music as described in this survey have been achieved through careful studies of the actual musical manuscripts and prints in the collection. Various external documents and a knowledge of historical circumstances have been of importance for contextualizing the philological observations. Yet the most important source of information has been the data extracted from the sources themselves, read and interpreted from a broad perspective not merely as vehicles for music but also as artefacts of material culture. The detailed database and the digitized images have been of great use, but mainly for sorting and searching the vast material. The most important conclusions are the result of patient philological work and close attention to detail. This combination of new and old - modern technologies allied to traditional and well-tried methods and the integration of cultural-theoretical perspectives - suggests a most promising path for the future development of historical musicology.

${ }^{49}$ Schildt, Gustav Düben at Work, 310-318.

${ }^{50} \mathrm{See}$ http://www2.musik.uu.se/duben/Concordances.pdf.

${ }^{51}$ For a comprehensive study of these practices, see Schildt, Gustav Düben at Work. 


\section{Bibliography}

Assig, Johann von. Herrn Hannß von Aßig, Weyland Sr. Chur-Fürstl. Durchl. zu Brandenburg gewesenen Hauptmanns, und des Schlosses und Burg-Lehns Schwiebuß Directoris, Gesammlete Schrifften. Breslau: Michael Hubert, 1719. http://vd18.de/de-slub-vd18/ content/titleinfo/9581743.

Berglund, Lars. Studier i Christian Geists vokalmusik. Studia musicologica Upsaliensia

21. Uppsala: Acta Universitatis Upsaliensis, 2002.

. "The Roman Connection: Dissemination and Reception of Roman Music in the

North." In The Dissemination of Music in Seventeenth-Century Europe: Celebrating the Düben Collection, edited by Erik Kjellberg, 193-218. Varia musicologica 18. Bern: Peter Lang, 2010.

Berglund, Lars, and Maria Schildt. "French Stage Music in the Düben Collection, Uppsala: A Düben-Philidor Connection.” In Les Cordes de l'orchestre français sous le règne de Louis XIV, edited by Jean Duron and Florence Gétreau. Paris: Éditions Vrin, forthcoming.

"Italian Music at the Swedish Royal Court of Queen Christina." (Forthcoming).

Grusnick, Bruno. "Die Dübensammlung: ein Versuch ihrer chronologischen Ordnung."

Pts. 1-3. Svensk tidskrift för musikforskning 44 (1964): 27-82; 46 (1966): 63-186.

Lindberg, Folke. "Katalog över Dübensamlingen i Uppsala Universitets Bibliotek." Licentiate diss., Uppsala University, 1947.

Kjellberg, Erik. "Kungliga musiker i Sverige under stormaktstiden: studier kring deras organisation, verksamheter och status ca 1620 - ca 1720.” 2 vols. PhD diss., Uppsala University, 1979.

Peetz-Ullman, Anna-Juliane. "Eine neue Quelle zu Gustav Dübens Reisen.” Svensk tidskrift för musikforskning 94 (2012): 65-76.

Pomian, Krzysztof. Collectionneurs, amateurs et curieux: Paris, Venise: XVIe-XVIIIe siècle. Paris: Gallimard, 1987.

Robertson, Michael. The Courtly Consort Suite in German-Speaking Europe, 1650-1706. Farnham: Ashgate, 2009.

Rudén, Jan Olof. "Vattenmärken och musikforskning: presentation och tillämpning av en dateringsmetod på musikalier i handskrift i Uppsala universitetsbiblioteks Dübensamling.” Licentiate diss., Uppsala University, 1968.

Schildt, Maria. "Gustav Düben at Work: Musical Repertory and Practice of Swedish Court Musicians, 1663-1690.” PhD diss., Uppsala University, 2014.

Seventeenth-Century Instrumental Dance Music in Uppsala University Library Instr.mus. hs 409. Monumenta musicae Svecicae 8, edited by Jaroslav J. S. Mráček. Stockholm: Ed. Reimers, 1976.

Webber, Geoffrey. "Italian Music at the Court of Queen Christina: Christ Church, Oxford, Mus. MS 377 and the Visit of Vincenzo Albrici's Italian Ensemble, 1652-54." Svensk tidskrift för musikforskning 75, no. 2 (1993): 47-53.

Wollny, Peter. "A Source Complex from Saxony." In The Dissemination of Music in Seventeenth Century Europe: Celebrating the Düben Collection, edited by Erik Kjellberg, 174-191. Varia musicologica 18. Bern: Peter Lang, 2010. 
. "Beiträge zur Entstehungsgeschichte der Sammlung Düben." Svensk tidskrift för musikforskning 87 (2005): 100-14.

. "Zur Thüringer Rezeption des französischen Stils im späten 17. und frühen 18. Jahrhundert." In Ständige Konferenz Mitteldeutsche Barockmusik in Sachsen, Sachsen-Anhalt und Thüringen, Jahrbuch 2001, edited by Wilhelm Seidel and Peter Wollny, 140-152. Schneverdingen: Verlag Karl Dieter Wagner, 2003.

\author{
POTI V DÜBNOVO ZBIRKO \\ KAKO STA GUSTAV DÜBEN IN NJEGOV SIN PRIDOBIVALA MUZIKALIJE
}

\title{
Povzetek
}

Dübnovo zbirko, ki jo danes hrani Univerzitetna knjižnica v Uppsali (S-Uu), so ustvarili člani družine Düben med okoli 1645 in 1726, univerzi pa so jo poklonili leta 1732. Najpomembnejša člana te družine sta bila Gustav Düben starejši in njegov sin Anders von Düben, ki je zbirko predal univerzi. Zbrana glasba odraža potrebe njunih vlog dvornih kapelnikov in organistov nemške cerkve. Zbirka vsebuje blizu dva tisoč del v rokopisih in vsaj sto petdeset glasbenih tiskov, ki so vsi digitalizirani in katalogizirani ter v taki obliki dostopni tudi v spletni zbirki The Düben Collection Database Catalogue.

Po zaslugi nedavnih raziskav Marie Schildt in Petra Wollnyja lahko danes izsledimo več poti, po katerih so glasbene vire za to obsežno zbirko pridobivali. Velik del rokopisov predstavljajo kopije glasbenih tiskov, ki so jih izdajali nemški in nizozemski tiskarji. Zanimive so tudi druge obsežne skupine skladb tujega izvora, ki so krožile samo v rokopisnih prepisih, prihajale pa so na primer iz Rima, mesta Gdansk, regije Lübecka in Hamburga, iz dvora Gottorf, s Saške, iz Vroclava, Dunaja in Pariza. V zbirki je tudi skupina rokopisov, ki so nastali na Švedskem in za katere ne poznamo tujih predlog. Nekateri so delo skladateljev, ki so delovali v Stockholmu, kot je bil na primer Christian Geist. Za večji del, ki obsega okoli dvesto petdeset rokopisov, pa izvor še ni bil ugotovljen oziroma preverjen. Avtor prispevka meni, da bi morda povezavo lahko iskali v Hamburgu.

Poti, ki so se jih posluževali Dübnovi za pridobivanje glasbene literature, so bile v največji meri odvisne od osebnih kontaktov in mrež in so bile v nekaj primerih tudi zgolj posledica slučajev. A glasba sama je bila vedno izbrana s posebnim posluhom za glasbeno kakovost in uporabnost. Veliko del je bilo posebej prilagojenih lokalnim razmeram.

$\mathrm{Na}$ koncu je treba vendarle poudariti, da so največ podatkov za opravljeno raziskavo in njeno metodologijo dali sami rokopisi in tiski ter le v manjši meri drugo gradivo. Podatkovna zbirka je služila predvsem za urejanje in križno iskanje, osnovno pa je bilo temeljno delo po tradicionalnih filoloških metodah. 